\title{
Effect of testosterone propionate on hippocampal pyramidal neuron number in female rats
}

\author{
Masallah Candemir ${ }^{1}$,MD, Serap Semiz ${ }^{2}$,MD, Goksin Nilufer Yonguc ${ }^{3}$, MD, Mehmet Bulent Ozdemir ${ }^{4}$, MD, PhD, \\ Gulcin Abban-Mete ${ }^{5}$, PhD, Esat Adiguzel $^{4}$, MD
}

\begin{abstract}
INTRODUCTION The hippocampus is an important region of the brain that regulates cognitive and emotional functions. In this study, we examined the impact of perinatal administration of testosterone propionate (TP) on the number of pyramidal neurons in the CA1 and CA3 regions of the hippocampi of female rats.

METHODS Five groups of rats were used in this study. Three groups of female rats were administered TP in either both the prenatal and the postnatal periods (Group 1), only the prenatal period (Group 2) or only the postnatal period (Group 3). The other two groups of rats included control females (Group 4) and control males (Group 5). The rats were sacrificed on postnatal Day 120 and their brains were analysed for hippocampal pyramidal neuron number using stereological methods.

RESULTS Control male rats (Group 5; $p=0.043)$ and TP-treated female rats in Groups $1(p=0.012)$ and 2 $(p=0.037)$, but not Group $3(p>0.05)$, had a significantly higher number of pyramidal neurons than control female rats (Group 4). The rats in Group 1 had the highest number of pyramidal neurons among the female rats.

CONCLUSION Perinatal TP treatment has an augmenting effect on the number of pyramidal neurons in the hippocampi of female rats. We also found gender-based differences in the hippocampi of male and female rats, with a higher number of pyramidal neurons seen in male rats. Continuous TP administration during the prenatal and postnatal periods is more effective than administration only in the prenatal or postnatal period.
\end{abstract}

Keywords: androgens, female, perinatal, rat, stereology

\section{INTRODUCTION}

Gonadal steroids have important functions in all periods of life. According to the literature, these hormones have crucial effects on brain development. (1) Oestrogen and testosterone are well known gonadal steroids that have different effects on brain development in the two genders. ${ }^{(2-4)}$ As a result of these effects, brain maturation, behavioural characteristics and physical characteristics become specific to the two genders. ${ }^{(1-4)}$

Although the effect of hippocampal functions on cognition is not thoroughly explained even to this day, their relevance has been widely accepted since the beginning of the 20th century. ${ }^{(5)}$ Previous studies have shown that prenatal manipulation of gonadal steroids can reverse gender differences in the hippocampus, a finding that correlates with behavioural tests performed on adult animals. ${ }^{(2-4,6,7)}$ Some authors have established that the volume of the pyramidal cell layer and the neuronal morphology of the hippocampus are masculinised in female rats by perinatal and early postnatal administration of testosterone propionate (TP).. ${ }^{(1,7)}$ Isgor and Sengelaub reported that male rats had larger CA1 and CA3 pyramidal cell field volumes and soma size than female rats. ${ }^{(3)}$ They also showed that testosterone and dihydrotestosterone treatment leads to masculinisation in female rats, while flutamide treatment leads to feminisation in male rats. ${ }^{(3)}$ Zhang et al showed that the number of bromodeoxyuridine positive cells in female rats were increased with TP and dihydrotestosterone treatment. ${ }^{(8)}$ Xiao and Jordan reported a higher number of androgen receptors and hippocampal CA1 pyramidal cells in the left hemisphere than in the right, but only in gonadally intact male rats, and in female rats given TP. ${ }^{(9)}$ All these studies indicate that experimental hormonal manipulations of laboratory rodents alter not only the functions but also the number of neurons.

Stereological methods provide more reliable data than semiquantitative methods in the estimation of the total number of neurons. West et al developed the optical fractionator, a method that combines an optical dissector and a systematic uniform sampling scheme fractionator. ${ }^{(10)}$ In our study, the optical fractionator was preferred for estimating the total number of pyramidal neurons since the method is more useful and easier to perform than other stereological methods, such as the physical dissector. ${ }^{(10,11)}$ These keystone studies guided our hypothesis and led to the current experiment.

There is insufficient information about the time-related effects of perinatally administered androgens on the total number of pyramidal neurons in the hippocampus. In this study, we hypothesised that long-term androgen treatment during the perinatal period in female rats would increase the number of pyramidal neurons in the hippocampus more effectively than short-term androgen treatment. To test this hypothesis, TP was administered to female rats during the prenatal and early

\footnotetext{
${ }^{1}$ Department of Pediatrics, Beylikduzu Kolan Hospital, Istanbul, ${ }^{2}$ Department of Pediatric Endocrinology, Acibadem Healthcare Group, Bagdat Caddesi Medical Center, Istanbul, ${ }^{3}$ Department of Anatomy, School of Medicine, Izmir University, Izmir, ${ }^{4}$ Department of Anatomy, School of Medicine, Pamukkale University, ${ }^{5}$ Department of Histology-Embryology, School of Medicine, Pamukkale University, Denizli, Turkey

Correspondence: Dr Esat Adiguzel, Professor, Department of Anatomy, School of Medicine, Pamukkale University, Denizli 20020, Turkey. esatadiguzel@yahoo.com
} 
postnatal periods. The left brain hemispheres of all rats were selected for the estimation of hippocampal pyramidal neuron numbers, following which the total number of pyramidal neurons in the hippocampal CA1, CA2 and CA3 regions of the rats were estimated using the optical fractionator method.

\section{METHODS}

Wistar albino female rats $(n=12)$ were purchased from the Animal Research Laboratory of Pamukkale University, Turkey. Female rats whose vaginal smears revealed polygonal superficial cells on microscopic inspection were housed together with one male rat overnight, three female rats at a time. Day 0 of gestation was taken to be the day on which a sperm-positive vaginal smear or a vaginal plug presence was observed. Pregnant female rats were then individually housed in different cages. The cages had a plastic base and a stainless steel covering, and were placed in an animal room. The environmental conditions of the animal room were controlled (temperature: $22 \pm 2{ }^{\circ} \mathrm{C}$; humidity: $50 \pm 5 \%$; 12 -hour dark/light cycle). Two pregnant rat groups (6 rats in each group) were randomly assigned on gestation Day 16 to receive either intraperitoneal $1 \mathrm{mg}$ TP in $0.5 \mathrm{~mL}$ sesame oil or $0.5 \mathrm{~mL}$ pure sesame oil every morning (i.e. daily) until parturition. The gender of the pups was determined by measuring the anogenital distance, following which the pups were randomly assigned to five groups after birth (Table I). The day of birth was marked as postnatal Day 0 .

The two groups of female pups whose dams had been treated with TP were assigned to receive either $100 \mu \mathrm{g}$ TP in $0.1 \mathrm{~mL}$ sesame oil (Group 1) or $0.1 \mathrm{~mL}$ pure sesame oil (Group 2) by subcutaneous injection around the neck on postnatal Days $0-3$. Female pups of the dams treated with pure sesame oil were also assigned to receive either $100 \mu \mathrm{g}$ TP in $0.1 \mathrm{~mL}$ sesame oil (Group 3) or $0.1 \mathrm{~mL}$ pure sesame oil (Group 4) by subcutaneous injection around the neck on postnatal Days 0-3. Group 5, which consisted of the male pups of dams treated with pure sesame oil, was similarly treated with $0.1 \mathrm{~mL}$ sesame oil on postnatal Days 0-3. The study procedure is summarised in Table I. Pups were housed with their dams in the same cage and under the same laboratory conditions until postnatal Day 21. Thereafter, the pups were separated from their dams and kept in different cages until postnatal Day 120, on which they were sacrificed.

On postnatal Day 120, the rats were transcardially perfused with $150 \mathrm{~mL}$ saline $(0.9 \%$ sodium chloride) to rinse the vessels, and with $400 \mathrm{~mL}$ of $4 \%$ paraformaldehyde solution in phosphate buffer $(0.1 \mathrm{M}, \mathrm{pH}$ 7.4) for fixation. The brains of the rats were removed and immersed in $30 \%$ sucrose solution at $4{ }^{\circ} \mathrm{C}$ for two days before sectioning. The brains were placed in a cryostat chamber (Leica CM3050; Leica Microsystems Nussloch GmbH, Nussloch, Germany) for sectioning, and coronal sections of $100 \mu \mathrm{m}$ thickness were cut serially at $-15^{\circ} \mathrm{C}$ to $-20^{\circ} \mathrm{C}$. Every fourth section was taken, according to systematic uniform
Table I. Study procedure and group features.

\begin{tabular}{|c|c|c|}
\hline Group & Gender (No.) & Treatment \\
\hline 1 & Female (5) & $\begin{array}{l}\text { - Dams received intraperitoneal } 1 \mathrm{mg} \\
\text { TP in } 0.5 \mathrm{~mL} \text { sesame oil daily } \\
\text { - Pups were administered } 100 \mu \mathrm{g} \text { TP in } \\
0.1 \mathrm{~mL} \text { sesame oil subcutaneously on } \\
\text { postnatal Days } 0-3\end{array}$ \\
\hline 2 & Female (5) & $\begin{array}{l}\text { - Dams received intraperitoneal } 1 \mathrm{mg} \\
\text { TP in } 0.5 \mathrm{~mL} \text { sesame oil daily } \\
\text { - Pups were administered } 0.1 \mathrm{~mL} \\
\text { sesame oil subcutaneously on } \\
\text { postnatal Days } 0-3\end{array}$ \\
\hline 3 & Female (5) & $\begin{array}{l}\text { - Dams received intraperitoneal } 0.5 \mathrm{~mL} \\
\text { sesame oil daily } \\
\text { - Pups were administered } 100 \mu \mathrm{g} \text { TP in } \\
0.1 \mathrm{~mL} \text { sesame oil subcutaneously on } \\
\text { postnatal Days 0-3 }\end{array}$ \\
\hline $4^{*}$ & Female (5) & $\begin{array}{l}\text { - Dams received intraperitoneal } 0.5 \mathrm{~mL} \\
\text { sesame oil daily } \\
\text { - Pups were administered } 0.1 \mathrm{~mL} \\
\text { sesame oil subcutaneously on } \\
\text { postnatal Days } 0-3\end{array}$ \\
\hline $5^{*}$ & Male (5) & $\begin{array}{l}\text { - Dams received intraperitoneal } 0.5 \mathrm{~mL} \\
\text { sesame oil daily } \\
\text { - Pups were administered } 0.1 \mathrm{~mL} \\
\text { sesame oil subcutaneously on } \\
\text { postnatal Days } 0-3\end{array}$ \\
\hline
\end{tabular}

${ }^{*}$ Groups 4 and 5 were control groups. TP: testosterone propionate

random sampling rules, and mounted on gelatin-coated slides for staining. ${ }^{(10)}$ The mounted sections were immersed in xylene for 10 minutes and an ethanol series (consecutive 100\%, 100\%, $70 \%$ and $50 \%$ ethanol solutions at 5-minute intervals) for hydration. Subsequently, the sections were stained with cresyl violet for 5 minutes, washed in running tap water, rinsed in distilled water, dehydrated in an ethanol series (consecutive 50\%, $70 \%, 100 \%, 100 \%$ ethanol solutions at 5 -minute intervals) and immersed in xylene for 10 minutes. The stained sections were coated with methyl methacrylate (Micromount ${ }^{\circledR}$; Surgipath Medical Industries Inc, Toronto, Canada) and covered with a cover slip.

For microscopic analysis, a microscope (Olympus CX31; Olympus Europa Holding GmbH, Hamburg, Germany) equipped with a microcator (Heidenhain MT-12, ND 221 B; Dr. Johannes Heidenhain $\mathrm{GmbH}$, Traunreut, Germany) and a video camera (SSc-DC88P; Sony, Tokyo, Japan), which was connected to a monitor (LMD-2010; Sony, Tokyo, Japan), was used. A series of ten or twelve brain sections that traversed the hippocampus were used from each brain to count the number of hippocampal pyramidal neurons. Real-time images from the pyramidal cell layers of the hippocampus were obtained using the microscope. The boundaries of the pyramidal cell layer of the hippocampus were first detected using the $4 \times$ objective, after which a $100 \times$ oil objective was used to measure thicknesses and count cells. Features of the hippocampus proper were identified in the sections, approximately 1.72-6.84 mm behind the bregma, according to Paxinos and Watson's The Rat Brain in Stereotaxic Coordinates. ${ }^{(12)}$ The pyramidal neurons were 
Table II. Key findings of the study.

\begin{tabular}{lllll}
\hline Group & \multicolumn{2}{c}{ Mean \pm SD) } & CE & CV \\
\cline { 2 - 3 } & Body weight* $^{*}(\mathbf{g})$ & $\begin{array}{c}\text { Estimated total no. of } \\
\text { pyramidal neurons }\end{array}$ & & \\
\hline 1 & $193.40 \pm 4.31$ & $183,998.8 \pm 16,401.0$ & 0.016 & 0.089 \\
2 & $183.18 \pm 4.05$ & $178,755.6 \pm 18,648.0$ & 0.015 & 0.115 \\
3 & $182.96 \pm 8.99$ & $164,983.0 \pm 20,593.9$ & 0.023 & 0.072 \\
4 & $177.38 \pm 4.85$ & $146,847.2 \pm 11,957.4$ & 0.019 & 0.126 \\
5 & $197.24 \pm 5.50$ & $177,986.8 \pm 10,267.3$ & 0.019 & 0.057 \\
\hline
\end{tabular}

*One-way ANOVA $(p=0.000) .{ }^{\dagger}$ One-way ANOVA $(F=4.35 ; p=0.011)$

ANOVA: analysis of variance; CE: estimated intra-animal coefficient of error for the estimated total number of pyramidal neurons; CV: observed inter-animal coefficient of variation; SD: standard deviation

defined according to the literature, ${ }^{(13,14)}$ and the distance between the upper and lower surfaces of the sections was measured using a microcator in every dissector sample. ${ }^{(10,11)}$

The optical fractionator method was used for counting pyramidal neurons in the hippocampus. ${ }^{(10)}$ A two-dimensional unbiased counting frame with an area of $20 \times 20 \mu \mathrm{m}^{2}$ was used to count the cells. The section sampling fraction was 0.25 , and the area sampling fraction was 0.016 in all rat groups. The height sampling fraction was calculated by dividing the height of the dissector by the height of the section. The total pyramidal neuron number of the hippocampus was estimated using the following formula: $N=(\Sigma Q-) \times(1 /$ ssf $)(1 /$ asf $) \times(1 / h s f)$, where $\mathrm{N}=$ neuron number; $\mathrm{Q}-$ = counted total pyramidal neuron number; ssf = section sampling fraction; asf = area sampling fraction; and hsf = height sampling fraction.

The estimated intra-animal coefficient of error for the estimated total number of pyramidal neurons and the observed inter-animal coefficient of variation were calculated in accordance with the methodology outlined by West et $\mathrm{al}^{(10)}$ and Hosseini-Sharifabad and Nyengaard. ${ }^{(14)}$ Volume shrinkage was not taken into consideration for calculating the total number of pyramidal neurons. All data were collected from the left hemispheres as a higher number of androgen receptors and hippocampal CA1 pyramidal cells have been reported to be present in the left hemisphere. ${ }^{(9)}$ Variables were analysed using one-way analysis of variance (ANOVA) followed by Tukey post-hoc test.

\section{RESULTS}

The dams' mean weight on gestation Day 16 was $290 \pm 12 \mathrm{~g}$ in the TP-treated group $(n=6)$ and $284 \pm 11 \mathrm{~g}$ in the sesame oil-treated group $(n=6)(p>0.05)$. The mean birth weights of the pups whose dams were treated with TP was $7.8 \pm 0.2 \mathrm{~g}$, while that of those whose dams were treated with sesame oil was $8.2 \pm 0.8 \mathrm{~g}(\mathrm{p}>0.05)$. The mean body weights of the rats in Groups 1-5 were measured before sacrifice, and the data are presented in Table II and Fig. 1. There were statistically significant differences among the groups $(p=0.000)$. The control male rats in Group 5 and the female rats in Group 1 had significantly higher body weights than the control female rats in Group 4.

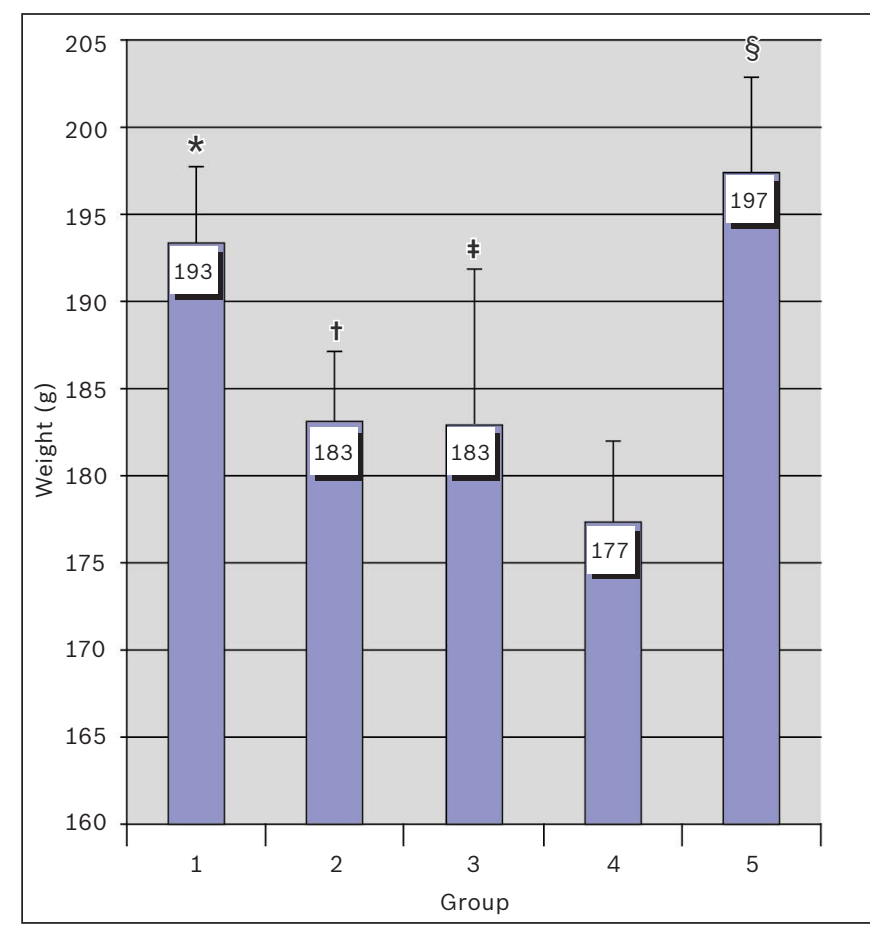

Fig. 1 Mean body weight (rounded up) of rats before sacrifice on postnatal Day 120. One-way ANOVA and Tukey post-hoc tests showed statistically significant differences between the groups.

ANOVA: analysis of variance

*Group 1 vs. Group $4(p=0.003) .{ }^{+}$Group 2 vs. Group $5(p=0.008)$. ‡Group 3 vs. Group $5(p=0.0078$. §Group 4 vs. Group $5(p=0.000)$.

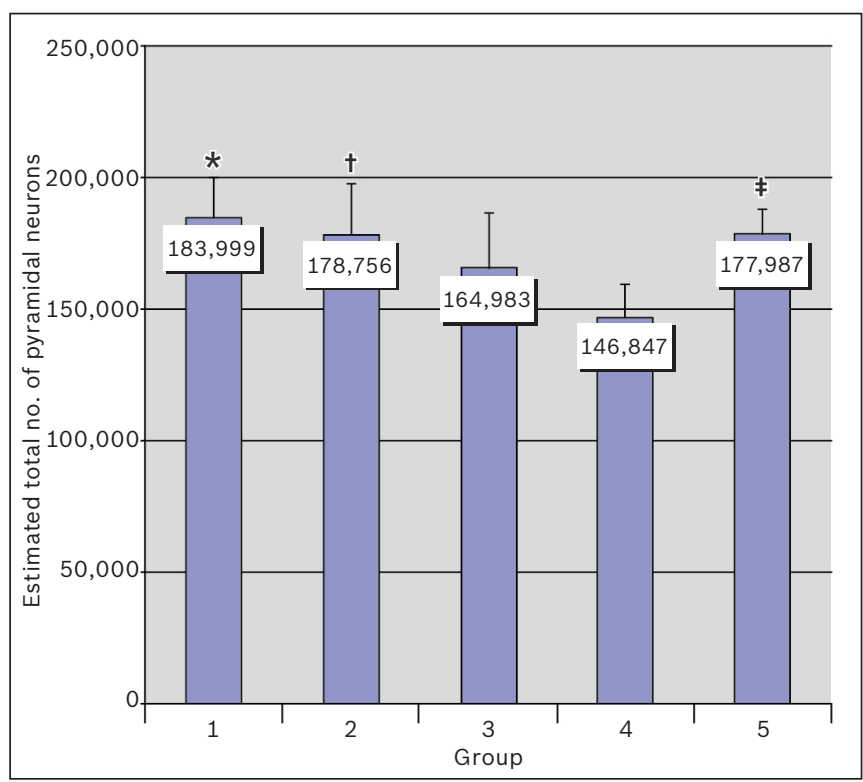

Fig. 2 Mean total number (rounded up) of pyramidal neurons in the hippocampi of the rats in the various groups. One-way ANOVA and Tukey post-hoc test showed statistically significant differences between the groups.

ANOVA: analysis of variance

${ }^{*}$ Group 4 vs. Group $1(p=0.012) .{ }^{\dagger}$ Group 4 vs. Group $2(p=0.037)$ ${ }^{\star}$ Group 4 vs. Group $5(p=0.043)$.

The difference between the means of the estimated total number of pyramidal neurons of the various groups was statistically significant $(p=0.011)$. Compared to the control female rats group (Group 4), a significantly higher total number of pyramidal neurons was found in the control male group (Group 5; $p=0.043$ ) and the TP-treated females in Group 1 $(p=0.012)$ and Group $2(p=0.037)$, but not Group 3 


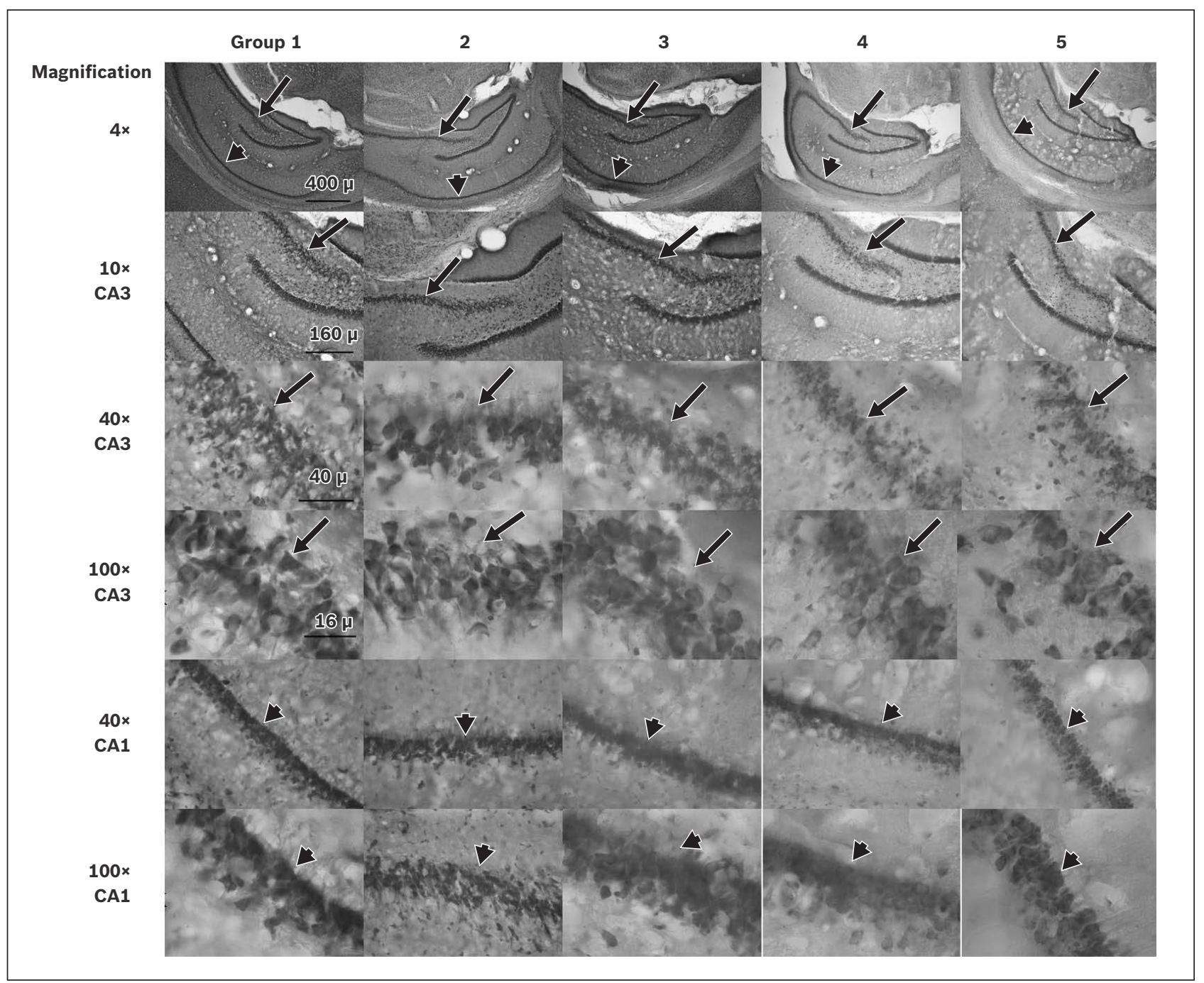

Fig. 3 Photomicrographs of the cresyl violet-stained hippocampal sections of rats from the various groups. Images in columns 1-5 show sections from rats in Groups 1-5, respectively. Row 1 images show coronal sections of CA3, CA1 and the dentate gyrus. Rows 2-4 show the CA3 pyramidal layer. Rows 5-6 show the CA1 pyramidal layer. Arrows indicate the CA3 pyramidal layer, while arrowheads mark the CA1 pyramidal layer.

(Fig. 2). Comparative photographs of the coronal sections of the hippocampal regions from the various groups are shown in Fig. 3. There was no demonstrative difference apparent between the various groups.

Treatment with TP improved the body weight and total number of pyramidal neurons in the hippocampi of female pups. Group 1 rats had the highest neuron number among all the female rats. These results suggest that long-term androgen treatment during the perinatal period may be more potent in improving the total number of pyramidal neurons than prenatal or postnatal androgen treatment.

\section{DISCUSSION}

Our results indicate that perinatal TP administration caused masculinisation in female rats, as previously reported. ${ }^{(15)}$ Demissie et al $^{(15)}$ reported that prenatally androgenised rats exhibited significantly increased body weight, and the findings of our study concur. We found statistically significant differences between the mean body weights of rats on postnatal Day 120, although such differences were not observed at birth. Although the anabolic effect of androgens is well known, it may be worth investigating how TP treatment during the early stages of life affects body weight in the later stages.

Current data indicates that there are significant differences in the morphology, volume and number of pyramidal neurons in the hippocampal CA1, CA2 and CA3 regions in wild-type adult rat brains between different genders, with male rats showing a higher number of pyramidal neuron and neuronal dendrite than females. ${ }^{(3,8,15,16)}$ It has also been reported that exposure to TP in the perinatal period significantly reverses such gender differences in the pyramidal neuron layer of the hippocampi of female or castrated male rats. ${ }^{(3,16)}$ In our study, treatment with TP during the prenatal and postnatal periods or only in the prenatal period significantly changed the number of hippocampal pyramidal neurons in female rats. Postnatal TP treatment, however, did not produce statistically significant effects. These findings are in disagreement with the Isgor and Sengelaub study, which suggested that continuous treatment with TP in the late prenatal and early postnatal periods are 
ineffective in increasing the number of pyramidal neurons in adult female and castrated male rats. ${ }^{(3)}$

Studies have reported the effects of gonadal steroids on the proliferation and morphology of pyramidal neurons, as well as the synaptic plasticity of the hippocampus. ${ }^{(3,7-9)}$ The brain was shown to be most sensitive to experimental hormonal manipulations during the developmental period. ${ }^{(3,7)}$ According to Isgor and Sengelaub, who studied the effects of prenatal gonadal steroids on the number and morphology of CA1 and CA3 pyramidal neurons in rats, exposure to androgens in the last week of gestation significantly increased hippocampal CA1 and CA3 pyramidal cell field volumes and neuronal soma size. ${ }^{(3)}$ However, they did not find any significant difference in the estimated total number of pyramidal neurons in the CA1 and CA3 regions between the two genders, and between the androgen-treated female rat groups and control rats. ${ }^{(3)}$ These findings are contrary to the results of our study.

It would be inadequate to attribute the observed discrepancies between the results of the two studies to methodological differences since Isgor and Sengelaub also used stereological methods (optical dissector and Cavalieri estimator), which are unbiased and as effective as the optical fractionator used in our study. However, in the Isgor and Sengelaub study, a total of approximately 50 pyramidal neurons per field per animal were sampled using a systematic random sampling procedure for sections and areas, ${ }^{(7)}$ while in our study, similar sampling procedures were used but 250-300 pyramidal neurons per animal were counted to estimate the total number of pyramidal neurons. The main difference between the two studies appears to be the duration of androgen treatment, and it is possible that the positive effects of androgen on the number of pyramidal neurons might be related to the duration of TP treatment. However, further research is needed to determine the mechanisms involved in the sexual dimorphism seen, with regard to the total number of pyramidal neurons.

Madeira et al found that the total number of CA1 pyramidal neurons displays sexual dimorphism in unmanipulated male and female rats aged 30 and 180 days. ${ }^{(17)}$ The study dealt with the selective vulnerability of hippocampal pyramidal neurons to hypothyroidism in rats, and found that sexual dimorphism in the total number of pyramidal neurons in the CA1 region was not affected by thyroid hormone manipulations. ${ }^{(17)}$ The results of our study had similar findings with Madeira et al's study regarding sexual dimorphism in the total number of pyramidal neurons in the hippocampus. However, while rats aged 30 and 180 days were used in the study by Madeira et al, rats in the foetal and neonatal period were treated in our study. Further differences existed between these two studies with regard to the kind of hormonal manipulation used and the duration of treatment. A study by Wimer and Wimer showed that there was greater granule cell density in the hippocampi of male mice compared to female mice of the same strain, in six different strains of mice. ${ }^{(18)}$ Notwithstanding differences with respect to the species of rodents used and the type of hippocampal cells assessed, the gender differences described by Wimer and Wimer were also found between the hippocampi of male and female rats in our study.

A study by West et al has suggested that volumetric changes, such as shrinkage and oedema, have an impact on the condensation and counting of neurons. ${ }^{(10)}$ For instance, Madeira et al reported that hypothyroidism induced a reduction in the volume of the pyramidal cell layer and caused a parallel increase in the numerical density of its neurons, although the total number of pyramidal neurons was not affected. ${ }^{(17)}$ The optical fractionator, which was the preferred method in the current study, allows for the estimation of the total number of pyramidal neurons without taking into consideration the volume of the pyramidal cell layer. ${ }^{(10)}$ Furthermore, in our study, the estimations of total number of pyramidal neurons were made for comparison between the various groups rather than for the exploration of the exact number of total pyramidal neurons. While it is possible to investigate hippocampal pyramidal neuron numbers using various counting and quantification methods - all of which have underlying assumptions and principles ${ }^{(19)}$ - we chose the optical fractionator in our study. However, we do not claim that the optical fractionator is the best option for estimating total cell numbers.

In summary, we found gender-based differences in the total number of pyramidal neurons in the hippocampi of male and female rats, with male rats showing a higher number of pyramidal neurons. This difference was also observed between female rat groups treated with TP and control rats, with perinatal TP treatment having an augmenting effect on the number of pyramidal neurons in the hippocampus. Continuous treatment with TP in the prenatal and early postnatal periods in female rats was more effective than administration in only the prenatal or postnatal periods. More studies will need to be conducted to shed light on the mechanisms by which testosterone produces such effects on hippocampal pyramidal neuron numbers.

\section{ACKNOWLEDGEMENTS}

The authors thank Ray W Guillery for helping us in the writing of the article. This study was supported by the Scientific Research Projects Fund (grant no. PAUBAP-2006/TPF/019) of the Pamukkale University, Denizli, Turkey.

\section{REFERENCES}

1. McCarthy MM, Konkle AT. When is a sex difference not a sex difference? Front Neuroendocrinol 2005; 26:85-102.

2. Hrabovszky Z, Hutson JM. Androgen imprinting of the brain in animal models and humans with intersex disorders: review and recommendations. J Urol 2002; 168:2142-8.

3. Isgor C, Sengelaub DR. Prenatal gonadal steroids affect adult spatial behavior, CA1 and CA3 pyramidal cell morphology in rats. Horm Behav 1998; 34:183-98.

4. Wolf CJ, Hotchkiss A, Ostby JS, LeBlanc GA, Gray LE Jr. Effects of prenatal 
testosterone propionate on the sexual development of male and female rats: a dose-response study. Toxicol Sci 2002; 65:71-86.

5. Papez JW. Visceral brain, its components parts and their connections. J Nerv Ment Dis 1958; 126:40-56.

6. Woodson JC, Balleine BW, Gorski RA. Sexual experience interacts with steroid exposure to shape the partner preferences of rats. Horm Behav 2002; 42:148-57.

7. Isgor C, Sengelaub DR. Effects of neonatal gonadal steroids on adult CA3 pyramidal neuron dendritic morphology and spatial memory in rats. J Neurobiol 2003; 55:179-90

8. Zhang JM, Konkle AT, Zup SL, McCarthy MM. Impact of sex and hormones on new cells in the developing rat hippocampus: a novel source of sex dimorphism? Eur J Neurosci 2008; 27:791-800.

9. Xiao L, Jordan CL. Sex differences, laterality, and hormonal regulation of androgen receptor immunoreactivity in rat hippocampus. Horm Behav 2002; 42:327-36

10. West MJ, Slomianka L, Gundersen HJ. Unbiased stereological estimation of the total number of neurons in the subdivisions of the rat hippocampus using the optical fractionator. Anat $\operatorname{Rec} 1991$; 231:482-97.

11. Gundersen HJ, Bagger P, Bendtsen TF, et al. The new stereological tools: disector, fractionator, nucleator and point sampled intercepts and their use in pathological research and diagnosis. APMIS 1988; 96:857-81.

12. Paxinos G, Watson C. The Rat Brain in Stereotaxic Coordinates. 6th ed. USA: Academic Press, Elsevier, 2007.

13. Paxinos G. Hippocampal formation. In: Paxinos G, ed. The Rat Nervous System. 3rd ed. USA: Academic Press, Elsevier, 2004: 637-87.

14. Hosseini-Sharifabad M, Nyengaard JR. Design-based estimation of neuronal number and individual neuronal volume in the rat hippocampus. J Neurosci Methods 2007; 162:206-14.

15. Demissie M, Lazic M, Foecking EM, et al. Transient prenatal androgen exposure produces metabolic syndrome in adult female rats. Am J Physiol Endocrinol Metab 2008; 295:262-8.

16. Hilton GD, Nuñez JL, McCarthy MM. Sex differences in response to kainic acid and estradiol in the hippocampus of newborn rats. Neuroscience 2003; 116:383-91.

17. Madeira MD, Sousa N, Lima-Andrade MT, et al. Selective vulnerability of the hippocampal pyramidal neurons to hypothyroidism in male and female rats. J Comp Neurol 1992; 322:501-18.

18. Wimer RE, Wimer C. Three sex dimorphisms in the granule cell layer of the hippocampus in house mice. Brain Res 1985; 328:105-9.

19. Guillery RW, Herrup K. Quantification without pontification: choosing a method for counting objects in sectioned tissues. J Comp Neurol $1997 ; 386: 2-7$.

\section{SMA EVENTS JULY - AUGUST 2013}

\section{DATE EVENT VENUE CME POINTS WHO SHOULD ATTEND? CONTACT}

CME Activities

\begin{tabular}{|c|c|c|c|c|c|}
\hline $\begin{array}{l}3 \text { July } \\
\text { Wednesday }\end{array}$ & Mastering Your Risk & $\begin{array}{l}\text { Sheraton Towers } \\
\text { Singapore }\end{array}$ & 2 & $\begin{array}{l}\text { Family Medicine and } \\
\text { All Specialties }\end{array}$ & $\begin{array}{l}\text { Margaret Chan } 62231264 \\
\text { margaret@sma.org.sg }\end{array}$ \\
\hline $\begin{array}{l}6 \text { July } \\
\text { Saturday }\end{array}$ & $\begin{array}{l}\text { A Medico-Legal Seminar: Understanding } \\
\text { Consent in Medical Practice } \\
\text { - Coming to Grips with the Legal } \\
\text { and Ethical Implications }\end{array}$ & Gleneagles Hospital & TBC & $\begin{array}{l}\text { Doctors and Healthcare } \\
\text { Professionals }\end{array}$ & $\begin{array}{l}\text { Denise Tan } 62231264 \\
\text { denisetan@sma.org.sg }\end{array}$ \\
\hline $\begin{array}{l}6 \text { July } \\
\text { Saturday }\end{array}$ & Mastering Professional Interactions & $\begin{array}{l}\text { Sheraton Towers } \\
\text { Singapore }\end{array}$ & 2 & $\begin{array}{l}\text { Family Medicine and } \\
\text { All Specialties }\end{array}$ & $\begin{array}{l}\text { Margaret Chan } 62231264 \\
\text { margaret@sma.org.sg }\end{array}$ \\
\hline $\begin{array}{l}10 \text { July } \\
\text { Wednesday }\end{array}$ & Mastering Adverse Outcomes & $\begin{array}{l}\text { Sheraton Towers } \\
\text { Singapore }\end{array}$ & 2 & $\begin{array}{l}\text { Family Medicine and } \\
\text { All Specialties }\end{array}$ & $\begin{array}{l}\text { Margaret Chan } 62231264 \\
\text { margaret@sma.org.sg }\end{array}$ \\
\hline $\begin{array}{l}13 \text { July } \\
\text { Saturday }\end{array}$ & SMA Seminar: Personal Data Protection Act & M Hotel Singapore & TBC & $\begin{array}{l}\text { Doctors and Healthcare } \\
\text { Professionals }\end{array}$ & $\begin{array}{l}\text { Denise Tan 6223 } 1264 \\
\text { denisetan@sma.org.sg }\end{array}$ \\
\hline $\begin{array}{l}16 \text { July } \\
\text { Tuesday }\end{array}$ & Mastering Difficult Interactions with Patients & $\begin{array}{l}\text { Sheraton Towers } \\
\text { Singapore }\end{array}$ & 2 & $\begin{array}{l}\text { Family Medicine and } \\
\text { All Specialties }\end{array}$ & $\begin{array}{l}\text { Margaret Chan 62231 } 264 \\
\text { margaret@sma.org.sg }\end{array}$ \\
\hline $\begin{array}{l}20 \text { July } \\
\text { Saturday }\end{array}$ & Mastering Difficult Interactions with Patients & $\begin{array}{l}\text { Sheraton Towers } \\
\text { Singapore }\end{array}$ & 2 & $\begin{array}{l}\text { Family Medicine and } \\
\text { All Specialties }\end{array}$ & $\begin{array}{l}\text { Margaret Chan 6223 } 1264 \\
\text { margaret@sma.org.sg }\end{array}$ \\
\hline $\begin{array}{l}25 \text { July } \\
\text { Thursday }\end{array}$ & Mastering Shared Decision Making & $\begin{array}{l}\text { Sheraton Towers } \\
\text { Singapore }\end{array}$ & 2 & $\begin{array}{l}\text { Family Medicine and } \\
\text { All Specialties }\end{array}$ & $\begin{array}{l}\text { Margaret Chan } 62231264 \\
\text { margaret@sma.org.sg }\end{array}$ \\
\hline $\begin{array}{l}28 \text { July } \\
\text { Sunday }\end{array}$ & Mastering Your Risk & $\begin{array}{l}\text { Sheraton Towers } \\
\text { Singapore }\end{array}$ & 2 & $\begin{array}{l}\text { Family Medicine and } \\
\text { All Specialties }\end{array}$ & $\begin{array}{l}\text { Margaret Chan } 62231264 \\
\text { margaret@sma.org.sg }\end{array}$ \\
\hline $\begin{array}{l}30 \text { July } \\
\text { Tuesday }\end{array}$ & Mastering Difficult Interactions with Patients & $\begin{array}{l}\text { Sheraton Towers } \\
\text { Singapore }\end{array}$ & 2 & $\begin{array}{l}\text { Family Medicine and } \\
\text { All Specialties }\end{array}$ & $\begin{array}{l}\text { Margaret Chan } 62231264 \\
\text { margaret@sma.org.sg }\end{array}$ \\
\hline $\begin{array}{l}3 \text { August } \\
\text { Saturday }\end{array}$ & Mastering Shared Decision Making & $\begin{array}{l}\text { Sheraton Towers } \\
\text { Singapore }\end{array}$ & 2 & $\begin{array}{l}\text { Family Medicine and } \\
\text { All Specialties }\end{array}$ & $\begin{array}{l}\text { Margaret Chan } 62231264 \\
\text { margaret@sma.org.sg }\end{array}$ \\
\hline $\begin{array}{l}11 \text { August } \\
\text { Sunday }\end{array}$ & BCLS/CPR + AED Courses & Alumni Medical Centre & 2 & Doctors and Clinic Staff & $\begin{array}{l}\text { Lin Shirong } 62231264 \\
\text { cpr@sma.org.sg }\end{array}$ \\
\hline $\begin{array}{l}15 \text { August } \\
\text { Thursday }\end{array}$ & Mastering Your Risk & $\begin{array}{l}\text { Sheraton Towers } \\
\text { Singapore }\end{array}$ & 2 & $\begin{array}{l}\text { Family Medicine and } \\
\text { All Specialties }\end{array}$ & $\begin{array}{l}\text { Margaret Chan } 62231264 \\
\text { margaret@sma.org.sg }\end{array}$ \\
\hline $\begin{array}{l}17 \text { August } \\
\text { Saturday }\end{array}$ & $\begin{array}{l}\text { SMA Seminar: Mediation \& Alternative } \\
\text { Dispute Resolution - Improving Dispute } \\
\text { Resolution Outcomes in Healthcare }\end{array}$ & M Hotel Singapore & TBC & $\begin{array}{l}\text { Doctors and Healthcare } \\
\text { Professionals }\end{array}$ & $\begin{array}{l}\text { Denise Tan } 62231264 \\
\text { denisetan@sma.org.sg }\end{array}$ \\
\hline $\begin{array}{l}21 \text { August } \\
\text { Wednesday }\end{array}$ & Mastering Adverse Outcomes & $\begin{array}{l}\text { Sheraton Towers } \\
\text { Singapore }\end{array}$ & 2 & $\begin{array}{l}\text { Family Medicine and } \\
\text { All Specialties }\end{array}$ & $\begin{array}{l}\text { Margaret Chan } 62231264 \\
\text { margaret@sma.org.sg }\end{array}$ \\
\hline $\begin{array}{l}27 \text { August } \\
\text { Tuesday }\end{array}$ & Mastering Shared Decision Making & $\begin{array}{l}\text { Sheraton Towers } \\
\text { Singapore }\end{array}$ & 2 & $\begin{array}{l}\text { Family Medicine and } \\
\text { All Specialties }\end{array}$ & $\begin{array}{l}\text { Margaret Chan } 62231264 \\
\text { margaret@sma.org.sg }\end{array}$ \\
\hline
\end{tabular}

